\title{
Big Data Processing and Evaluation of Education and Teaching
}

\author{
Jianhua ZHANG ${ }^{1, a_{*}, \text { Yijing XU }}{ }^{2, b}$ \\ ${ }^{1}$ General Education Center, Beijing Normal University Zhuhai Campus, China \\ ${ }^{2}$ General Education Center, Beijing Normal University Zhuhai Campus, China \\ a zhuhaijianhua@aliyun.com, ${ }^{\text {b } 845443202 @ q q . c o m}$,
}

Keywords: Education evaluation; the education of university; Teaching evaluation of era of large data

\begin{abstract}
Mainland China push for carrying out the education of institutions of higher Education and teaching evaluation work, many achievements, but differences also larger. This paper first reviews the development of education and teaching evaluation of higher education, then proposed that big data era of higher education brings huge influence, the it bring impact will be created new education idea, the new teaching system, the new teaching way and method, and the new education and teaching evaluation.
\end{abstract}

\section{Development Course of Education of Colleges and Universities and Teaching Assessment}

In modern China, with the introduction of western education, to 1898, the Qing government in all parts of the country's, new school had more than ten provinces and cities throughout this, Jingshi DaXueTang established, which has characters of the higher education of, marking the Chinese traditional imperial examination system had to decline, new education system began to gradually establish. After the revolution of 1911, under the influence of western educational thoughts, the Nanjing National Government published and promulgated a series of rules and regulations, from the central to local established the education Inspectorate management mechanism, to strengthen the management of education and supervision. In the thirty's of last Century, the Chinese modern education pioneer, Mr. Tao Xingzhi proposed that education evaluation theory and evaluation method of that time, which had a deep impact on that time. He stressed that to correctly and objectively evaluate a school, we must rely on scientific methods, the implementation of a comprehensive assessment of the comprehensive system. As for the evaluation method, the method of combining the relative evaluation and absolute evaluation, the method of self - Evaluation and the combination of his evaluation, quantitative evaluation and qualitative evaluation. This kind of idea, has the profound influence to the modern Chinese education, and has the practical significance.

After the founding of new China, the Chinese education comprehensive copied of the Soviet union education model, and the same period, this education and education research had increased the distance to western society. The cultural revolution in 1966, it is to make higher education into a mess, until the end of the cultural revolution, China began to enter the four modern, higher education had begun a new process.

1985 "decision on the reform of the educational system" is the Chinese government at the national level, the first time in the form of documents formally proposed "higher education assessment". This marks a new starting point for Chinese contemporary education and education assessment. In April 2004, the "2003-2007 education revitalization action plan" was formally proposed, the state established every 5 years of higher education evaluation system. In 2011, the Ministry of Education decided to start a new round of undergraduate teaching assessment from 2011.

Since May 2013, 2484 colleges had ordinary higher education enrollment qualification , the ordinary undergraduate course colleges and universities were 879 , higher vocational colleges 1266 , approved by the state and the establishment of the independent colleges 287 , through the national examination and approval of the branch college 52. In order to steadily and actively implement the higher education teaching quality engineering, China gradually exploring and established the college 
teaching evaluation system, and has of all colleges and universities to carry out the work of teaching evaluation.

\section{Specific Implementation and Operation of the Assessment}

The principles and guidelines of the teaching evaluation in China are" evaluating in order to promote the construction, to promote the reform, to promote the management, evaluation must combined with construction, focusing on building".

Specifically, "According to the Interim Provisions of the ordinary higher education assessment, the principle of ordinary institutions and colleges education evaluation is continue to executive the socialist orientation of running a school under the new situation, conscientiously implement the higher education always adhere to the for serving the socialist modernization construction, always adhere to the principle that the comprehensive development, and the higher education combined with labor and production, always put a firm and correct political direction in the first place, the training to adapt to the Chinese characteristic socialist construction can be the actual needs of the socialist builders and successors as the basic standard of college school running level and education quality evaluation."

The development of higher education and teaching evaluation in our country has the following positive significance: Promote the standardization of the teaching process of colleges and universities in china. Evaluation of the work, for the establishment of basic teaching quality and personnel training quality of the standard system and monitoring system, for the university teaching and management work to provide a certain significance of the system guarantee.

During the 2007 National two sessions, the CPPCC National Committee member, the University of petroleum professor Chen Mian said a negative comments, and cause social hot debate.

\section{My Point of View}

Classification of educational assessment in Colleges and Universities. I think, the education and teaching evaluation of colleges and universities should be divided into two levels: first level is, on national education policy, various colleges and universities in the education system of positioning. The second aspect is that the reform of the management system and management methods, and the reform of the teaching of the university. Although these two aspects of the relationship are inseparable, but there must be a difference. As for how to operate, the first is pay attention to assess situation, keep pace with the times, carry out assessment work. Secondly, the assessment should be scientific, systematic, standardized.

Evaluation of education in universities should be carried out with the evaluation of the quality education in primary and secondary schools at the same time together. Education and teaching evaluation, which is a systematic project involving the whole educational system of the state. Education and teaching reform in Colleges and universities is a part of the system. If cannot at the same time to carry out with the primary and middle school quality education evaluation working " linkage ", for China's overall education reform effect evaluation is difficult for conduct an overall, objective, comprehensive evaluation and summarize.

\section{The New Evaluation Will Have Significant Change}

Evaluating operation technical change. In the modern science, applied mathematics degree or has become a measure of the development of a science degree, and judging its theory is mature or not one of the important marks. Though I have objection to this view "education assessment has become a comprehensive discipline, interdisciplinary discipline", however, the mathematics and system science, management science, information science to be used for education science, I'm in favor of. 
The traditional analysis method of mathematical statistics, and big data analysis and data mining, will be a revolutionary impact on education evaluation.

On the assessment organization level change. "Education evaluation" will no longer be the single form of organization by the state and government organizations, may be more the private nonprofit organizations, professional service providers, and even education at all levels of the school itself, voluntarily in the evaluation. Because, this is really a good thing that has both social and economic benefits.

Changes in the concept level. The purpose of evaluation is to promote the progress of the work of higher education, the institutions of higher learning personnel training quality greatly improved, and make the students adapt to the social development changing requirements.

\section{Summary}

Over the years, the state attaches great importance to the quality of higher education, and put a lot of money. In order for the purpose of the school responsible, but also more consider the students responsible, accountable to parents, socially responsible, responsible to the country, we must stand in this height, to know and process higher education, higher education evaluation of this thing.

\section{References}

[1] Information on http://phycjy.pinghu.gov.cn/readnews.asp?id=3121

[2] Information on http://edu.ifeng.com/news/detail_2010_07/30/1859314_2.shtml

[3] Information on http://edu.ifeng.com/news/detail_2010_07/30/1859130_0.shtml

[4] Information on http://www.edu.cn/zong he 870/20100719/t20100719_497960_1.shtml

[5] Information on

http://wenku.baidu.com/link?url=UJ34XICSmjvCj9I7P4ekVPLmI5YiPMfjJ6D14cXVmCSFODmjn 8pxuAcXiXTdQFqFWdVuwN7f2zQtR86e IzXX7UKzIh5xLi47BohwNQRBO

[6]Information on http://edu.ifeng.com/news/detail_2010_07/30/1859314_2.shtml

[7] Guo Dacheng and Pang Haishao, 2015 College Quality Education Forum, Beijing Institute of Technology Press

[8] Guo Dacheng and Pang Haishao, 2013 College Quality Education Forum, Beijing Institute of Technology Press

[9] Guo Dacheng and Pang Haishao. 2012 College Quality Education Forum, Beijing Institute of Technology Press

[10] Jianhua Zhang, Zhe Zhang, Zhen Ge, General Education and Internet, Advances in Education Research/ Volume 22/ p.68

[11] Zhe Zhang, Jianhua Zhang, Zhen Ge, Comparison of Chinese and German Higher Education, Advances in Education Research/Volume 22/ p.81

[12] Jianhua Zhang, Zhen Ge, General Education and Practice in University, Advances in Education Research/Volume 4/ p.158 